\title{
RESEARCH
}

Open Access

\section{Lipid peroxidation diminishing perspective of isolated theaflavins and thearubigins from black tea in arginine induced renal malfunctional rats}

\author{
Ali Imran ${ }^{1 *}$, Muhammad Umair Arshad ${ }^{1}$, Muhammad Sajid Arshad ${ }^{1}$, Muhammad Imran³ ${ }^{3}$ Farhan Saeed
} and Muhammad Sohaib ${ }^{2}$

\begin{abstract}
Background: Recently oxidative stress induced maladies have amplified owing to sedentary lifestyle and monotonous diet. Introduction of plant based biomolecules may be a suitable strategy to cope with the lipid peroxidation. In this context, black tea polyphenols (theaflavin \& thearubigins) are in fame among the scientific community as cost effective therapeutic agents owing to their safety, economics, structural diversity and ability to modulate various lipid peroxidation responses by halting the expression of different metabolic targets.

Methods: The mandate of present investigation was to first time check the synergism among the isolated theaflavins \& thearubigins against lipid peroxidative indicators both in vitro and in vivo. Purposely, theaflavins and thearubigins were isolated from black tea through solvent partition methods by using different solvents (Aqueous ethanol, Aqueous methanol \& Water) and time intervals (30, 60 \& $90 \mathrm{~min}$ ) and subjected to in vitro characterization through different antioxidant indices to access the in vitro lipid peroxidation shooting effect of these bioactive moieties. Moreover, individual theaflavins contents also estimate through HPLC. For evaluation of in vivo antioxidant effect, renal malfunction was induced through arginine and forty rats were divided in four groups (10 each after power analysis) and 04 types of diets were given i.e. To (control diet without supplementation), T1 (Basic experimental Diet+ theaflavins supplementation @ 1 g), T2 (Basic experimental Diet+ Thearubigins supplementation @ $1 \mathrm{~g}$ ) \& T3 (Basic experimental Diet+ Supplementation of theaflavins+ thearubigins @ $0.5+0.5 \mathrm{~g}$, respectively) for the period of 56 days. Alongside, a control study was also carried out for comparison by involving normal rats fed on arginine free diet. The body weight, lipid profile, glycemic responses, Renal function test, liver function test, antioxidant indices and hematological parameters were estimated at the termination of study.
\end{abstract}

Results: The results indicated that theaflavins and thearubigins isolation was significantly affected by time of extraction and solvent. In this context, aqueous ethanol at 60 min extraction interval caused maximum extraction. Likewise, theaflavins isolate exhibited more antioxidant activity as compared to thearubigins. Moreover, the theaflavins and thearubigins based experimental diets imparted significant reduction in Lipid profile, glucose content, renal function tests and TBARS with enhancement in insulin, HDL and hematological parameters. In this context, theaflavin based diet caused maximum reduction in lipid profile and TBARS better as compared to thearubigins and theaflavins + thearubigins based. However, theaflavin+ thearubigins based diet caused highest glucose, urea \& creatinine decline and maximum insulin increase \& antioxidant indices as compared to other nutraceuticals. (Continued on next page)

\footnotetext{
* Correspondence: aliimran.ft@gmail.com; dr.aliimran@gcuf.edu.pk

${ }^{1}$ Institute of Home and Food Sciences, Government College University,

Faisalabad 38040, Pakistan

Full list of author information is available at the end of the article
}

(c) The Author(s). 2018 Open Access This article is distributed under the terms of the Creative Commons Attribution 4.0 International License (http://creativecommons.org/licenses/by/4.0/), which permits unrestricted use, distribution, and reproduction in any medium, provided you give appropriate credit to the original author(s) and the source, provide a link to the Creative Commons license, and indicate if changes were made. The Creative Commons Public Domain Dedication waiver (http://creativecommons.org/publicdomain/zero/1.0/) applies to the data made available in this article, unless otherwise stated. 
(Continued from previous page)

Conclusions: It was deduced that theaflavins \& thearubigins have strong antioxidative potential both in in vitro as well as in vivo to tackle the menace associated with lipid peroxidation.

\section{Background}

Globally, therapeutic worth of tea has been established against numerous maladies. The health escalating perspectives of tea has been attributed to his distinguished polyphenols. Accordingly, theaflavins and thearubigins are the promising polyphenols belong to subclass flavanolos. They produced when fresh tea leaves undergo enzymatic fermentation triggered by polyphenol oxidase and catalase resulted in structural variations in catechins thus formed theaflavin and thearubigins [1-3]. Structurally, theaflavin composed of catechins co-oxidation oriented benzotropolone skeleton coupled with dihydroxy and trihydroxy moiety at ortho- and vic-positions. Furthermore, oxidative modification of catechins and gallo-functional groups resulting in four major types of theaflavin along with some minor constituents [4]. Typically, theaflavin encompasses theaflavin (TF1), theaflavin-3-gallate (TF2A), theaflavin-3'gallate (TF2B) and theaflavin-3, 3'-digallate (TF3). Different catechins combinations are responsible for the diversity in theaflavin. Epicatechin combines with epigallocatechin and brings about TF1 while, EC and EGCG combine to form TF2A. Similarly, TF2B and TF3 are produced when ECG \& EGC and ECG \& EGCG bound to each other, respectively $[5,6]$. Theaflavin is a natural antioxidant \& metal chelator due to the presence of hydroxy groups however, the gallic acid moiety is also a contributory factor [7]. The majority of the studies have reported elevated antioxidant efficiency of theaflavin by esterification of hydroxyl ring with digallate esters [8]. Furthermore, it has been revealed that the inhibitory concentration $\left(\mathrm{IC}_{50}\right)$ of theaflavin as a superoxide scavenger is higher than epigallocatechin gallate (EGCG). Likewise, preventive role of theaflavin in lipid peroxidation is mainly attributed to its ability to cease the chain reaction. Apart from free radical scavenging and metal chelating abilities, theaflavin has potential to activate certain antioxidant enzymes like glutathione-S-transferase (GST), glutathione peroxidase (GPX), superoxide dismutase (SOD) and catalase (CAT) thereby reduces lipid peroxidation. Likewise, thearubigins or polymeric black tea polyphenols (PBPs) are the oxidative products of phenolics and their production accelerated after $75 \%$ conversion of catechins into flavan-3-ol molecules. They have ability to activate phase II enzymes by inducing transcriptional upregulation in lung and liver [9].

Chronic renal failure (CRF) is an irreversible loss to functioning nephrons resulting numerous disorders of blood vessels, glomeruli, tubules and renal interstitium [10]. Various investigations have explicated the protective effect of black tea polyphenols against renal failure. The preventive role lies in their ability to reduce uremic toxins, nitric oxide production and enhance overall antioxidant status. They up regulate blood urea nitrogen and glamorous filtration alongside improve liver performance [11].

The mandate of current investigation to isolate the theafavins and thearubigins from black tea Qi-men variety by using different solvents and time intervals, in vitro characterization and preparation of nutraceutical intervention against renal malfunctioning in arginine induced liver damage rats.

\section{Methods}

Black tea variety (Qi-Men) was procured from the National Tea Research Institute (NTRI), Shinkiari, Mansehra. The reagents (analytical and HPLC grade) and standards were purchased from Merck (Merck KGaA, Darmstadt, Germany) and Sigma-Aldrich (Sigma-Aldrich Tokyo, Japan). For efficacy trial, Male Sprague Dawley rats were housed in the Animal Room of Physiology department of GCUF. For biological assay, diagnostic kits were purchased from Sigma-Aldrich, Bioassay (Bioassays Chemical Co. Germany) and Cayman Chemicals (Cayman Europe, Estonia).

\section{Isolation of theaflavin and thearubigins}

Theaflavin and thearubigins were extracted by using water, methanol and ethanol at 30, 60 and $90 \mathrm{~min}$ intervals and isolated by solvent partition method [12]. Initially, extracts except water based were concentrated through Rotary Evaporator (Eyela, Japan) and after filtration subjected to solvent partition using chloroform, ethyl acetate and butanol. Theaflavin and thearubigins rich fractions were separated followed by rotary evaporation and freeze drying (CHIRST, Alpha 1-4 LD plus, Germany).

\section{HPLC quantification}

The isolated samples of theaflavins were characterized for their fractions through HPLC (PerkinElmer, Series 200 , USA). The conditions for HPLC were $C_{18}$ column (250 $\mathrm{mm} \times 4.6 \mathrm{~mm}, 5.0 \mu \mathrm{m}$ particle size), $10 \mu \mathrm{L}$ sample through auto sampler (WISP Model 710) and column temperature $40{ }^{\circ} \mathrm{C}$. The composition of mobile phase was acetonitrile, ethylacetate and $0.05 \%$ phosphoric acid 
in ratio of 21:3:76 with flow rate of $1 \mathrm{~mL} / \mathrm{min}$ and using on UV/vis detector (model 481) and measurement wavelength was $278 \mathrm{~nm}$.

\section{Indicators for lipid peroxidation}

Antioxidant capacity of isolated theaflavin and thearubigins fractions were determined through antioxidant indices including total antioxidant activity, free radical scavenging activity and ferric reducing antioxidant power as following methods. For this purpose, the isolated fractions both from theaflavin and thearubigins were mixed in water, methanol and ethanol $(1 \mathrm{mg} / \mathrm{mL})$ to be further utilized in antioxidant indices estimation.

\section{Total polyphenols}

Total phenolics of resultant isolates were estimated spectrophotometricaly using Folin-Ciocalteau method [13]. Briefly, equal amount of isolate in respective solvent and Folin- Ciocalteau reagent $(125 \mu \mathrm{L})$ and distilled water $(500 \mu \mathrm{L})$ were added and sty for $5 \mathrm{~min}$ at $22{ }^{\circ} \mathrm{C}$. Afterwards, $4.5 \mathrm{~mL}$ of sodium bicarbonate solution (7\%) was added to the mixture and absorbance was measured at $765 \mathrm{~nm}$ using a UV/vis Spectrophotometer (CECIL CE7200) against control and expressed results as $\mathrm{mg}$ gallic acid/100 g.

\section{Antioxidant activity}

$\beta$-carotene and linoleic acid assay was applied to measure the total antioxidant capacity [14]. Purposely, a mixture of $\beta$-carotene, chloroform, linoleic acid and Tween20was mixed at ratio of $2 \mathrm{mg}, 20 \mathrm{~mL}, 40 \mathrm{mg}$ and $400 \mathrm{mg}$, respectively. Chloroform was removed and $3 \mathrm{~mL}$ of the remained emulsion with $0.10 \mathrm{~mL}$ sample put in a water bath for reaction for two hours. Oxidation of $ß$-carotene was measured at $470 \mathrm{~nm}$ by using spectrophotometer.

\section{Free radical scavenging activity (DPPH assay)}

DPPH radical scavenging activity was measured according the procedure of [15]. Initially, DPPH $(1 \mathrm{~mL})$ was added to each extract $(4 \mathrm{~mL})$ and stay for $30 \mathrm{~min}$ on room temperature. The absorbance was noted at $520 \mathrm{~nm}$ using Spectrophotometer (CECIL CE7200).

\section{Ferric reducing antioxidant power (FRAP)}

The FRAP test was performed according to the guidelines of [16]. $0.5 \mathrm{~mL}$ of respective extract was added in phosphate buffer (1.25 mL, 0.2 M, pH 6.6) and potassium ferricyanide $(1.25 \mathrm{~mL}, 1 \%)$. After incubation, $10 \%$ TCA $(1.25 \mathrm{~mL})$ along with $0.1 \%$ ferric chloride were added in the mixture and then left at room temperature for $10 \mathrm{~min}$ and absorbance was measured at $700 \mathrm{~nm}$.

\section{Glucose diffusion}

Effect of isolated theaflavin and thearubigins fraction on glucose diffusion was assessed using glucose oxidase kit and $1.65 \mathrm{mM}$ D-glucose solution [17].

\section{Experimental diet preparation}

For biological assay, rats were divided in to four homogeneous groups fed on experimental diet. The common experimental diet was formulated using corn oil (10\%), protein $(10 \%)$, corn starch $(64 \%)$, cellulose $(10 \%)$, mineral (3\%) vitamin mixture (1\%) alongside arginine @ $2 \%$ for the induction of renal malfunctioning. For comparison a control study was also conducted by providing the normal diet (same composition except for arginine). However, common experimental diet from both studies further divided into four groups on the bases of addition of active ingredients, Diet 1 (Control, No active ingredient), Diet 2, (theaflavins supplementation @ $1 \mathrm{~g}$ ), Diet 3, (Thearubigins supplementation @ $1 \mathrm{~g}$ ) and Diet 4 (Supplementation of theaflavins+ thearubigins @ $0.5+0.5 \mathrm{~g}$, respectively). Afterwards All the ingredients were mixed then oven baked for $10 \mathrm{~min}$. The dose was selected by carried out a 21 days safety trial (Data not included).

In safety trial, rats were provided all the active ingredients orally @ of 250, 500, 1000, 1500, 2000 and $3000 \mathrm{mg} / \mathrm{kg}$-bw ( $n=6 \mathrm{rats} / \mathrm{dose})$. The treatments were given in both acute (single dose followed by a $48-\mathrm{h}$ observation period) and sub-acute (daily doses, except the highest, for 21 days). The hematological analysis as well as general physical examination was carried out [18].

\section{Study protocol}

To evaluate the therapeutic potential of tested compounds against renal malfunctioning an efficacy trial was planned. For the purpose, 50 male Sprague Dawley rats were housed in the Animal Room of Institute of Home \& Food Sciences, GCUF, Faisalabad. The protocol for this biological study was approved from Departmental ethical committee of GCUF that was in compliance with international standards ERC NO 2121. The rats were acclimatized by feeding on basal diet for a period of 1 week. The environmental conditions were control throughout the trial like temperature $\left(23 \pm 2{ }^{\circ} \mathrm{C}\right)$ and relative humidity $(55 \pm 5 \%)$ along with $12 \mathrm{~h}$ light-dark period. At the initiation of study, some rats (total 12 rats and average of results were considered as base line trend) were sacrificed to establish the baseline trend. For the induction of renal malfunctioning initially high arginine diet @ 2\% was administrated for a period of 7 days. During that tenure urea and creatinine levels were observed to estimate the onset of renal malfunctioning. Afterwards when values of both test deviate 25\% from normal then the original study was started. The study comprised of four groups of rats ten in each (Sample 
size according to power analysis). Accordingly, four types of experimental diets were given i.e. T0 (Basic experimental Diet), T1(Basic experimental Diet+ theaflavins supplementation@ 1 g/Kg B.W), T2 (Basic experimental Diet+ Thearubigins supplementation $1 \mathrm{~g} / \mathrm{Kg} \mathrm{B.W)} \mathrm{and} \mathrm{T3}$ (Basic experimental Diet+ Supplementation of theaflavins + thearubigins @ $0.5+0.5 \mathrm{~g} / \mathrm{Kg}$ B.W, respectively. During the 8 weeks trial, instantaneous administration of nutraceutical to experimental rats was ensured to assess their therapeutic role. At the termination of the study, overnight fasted rats were decapitated and blood was collected. For serum collection, blood samples were subjected to centrifugation using centrifuge machine @ 4000 rpm for $6 \mathrm{~min}$. The respective sera samples were examined for various biochemical assays by using Microlab 300, Merck, Germany. Different biochemical parameters including serum urea and creatinine status, liver function test, antioxidant status, lipid profile alongside glucose \& insulin and hematological analysis were accessed using respective commercial kits.

\section{Serum lipid profile}

Serum cholesterol level was assessed by using CHODPAP method, likewise, low density lipoproteins (LDL) by protocols of [19], high density lipoprotein (HDL) by HDL Cholesterol Precipitant method [20] and triglycerides level through liquid triglycerides (GPO-PAP) method [19].

\section{Serum glucose and insulin levels}

Glucose concentration was estimated by GOD-PAP method by following the protocol of [21], however, insulin level was determined by the method of [22].

\section{Kidney function test}

The serum samples were also analyzed for urea by GLDH-method and creatinine by Jaffe-method using commercial kits [23] to assess the renal functionality of different groups.

\section{Antioxidant status}

Glutathione contents were assessed by adapting the guidelines as mentioned by [24]. The reaction of product of GSH + DTNB in the protein free supernatant was estimated at $412 \mathrm{~nm}$ and expressed as $\mathrm{nmol} / \mathrm{mg}$ protein. Similarly, Plasma Malondialdehyde (MDA) was also measured by estimation the colored product formation at $532 \mathrm{~nm}$ by the reaction between Lipid peroxidation generates peroxide intermediates MDA with Thiobarbitutic Acid (TBA) [25].

\section{Safety assessment}

Liver function tests including aspartate aminotransferase (AST), alanine aminotransferase (ALT) and alkaline phosphatase (ALP) were assessed. Levels of AST and ALT were measured by the dinitrophenylhydrazene (DNPH) method using Sigma Kits 59-50 and 58-50, respectively and ALP by Alkaline Phosphates-DGKC method [26].

\section{Hematological aspects}

Red blood cells indices including total red blood cells (TRBCs), hemoglobin ( $\mathrm{Hb})$, hematocrit (Hct) and mean corpuscular volume (MCV) were estimated. Likewise, white blood cell indices including monocytes, lymphocytes and neutrophils were measured by using Automatic Blood Analyzer (Nihon Kohden, Japan) [27].

\section{Statistical analysis}

Statistical program SAS (version 9.1; Cary, NC) was utilized to analyze the data collected from this study. Two-way analysis of variance (ANOVA) was conducted to evaluate the effect of extraction time and solvent on polyphenol isolation. Moreover, One-way ANOVA were applied in efficacy trial and significance among the treatments were determined by applying LSD.

\section{Results}

Isolate characterization

Extraction yield

Means for extraction yield illuminated the significant effect of solvents $(p \geq 0.001)$ and time $(p \geq 0.002)$, highest theaflavin $(3.42 \pm 0.27 \mathrm{~g} / 100 \mathrm{~g})$ were detected in ethanolic extract followed by methanol $(2.77 \pm 0.25 \mathrm{~g} / 100 \mathrm{~g})$ whilst water exhibited the lowest yield $(2.32 \pm 0.13 \mathrm{~g} /$ 100 g). Similarly, solvent $(p \geq 0.001)$ \& time $(p \geq 0.001)$ also imparted pronounced impact for thearubigins, highest in ethanol and minimum in water. Extraction efficiency was also influenced by time and maximum yield for theaflavins and thearubigins was obtained at $60 \mathrm{~min} 3.41 \pm 0.17 \mathrm{~g} / 100 \mathrm{~g}$ and $13.17 \pm 0.59 \mathrm{~g} / 100 \mathrm{~g}$, respectively (Table 1 ).

\section{HPLC quantification of individual fractions of theaflavins}

The theaflavins fractions were significantly affected by solvents $(p \geq 0.001)$ and extraction time $(p \geq 0.0031)$ whilst their interactive effect showed non-significant trend $(p \geq 0.521)$. Means for TF1 indicated highest value $(2.18 \pm 0.06 \mathrm{mg} / \mathrm{g})$ in ethanolic extract followed by methanol $(1.96 \pm 0.03 \mathrm{mg} / \mathrm{g})$ and water $(0.751 \pm$ $0.001 \mathrm{mg} / \mathrm{g}$ ). However, effect of time revealed maximum output $(1.79 \pm 0.006 \mathrm{mg} / \mathrm{g})$ at $60 \mathrm{~min}$ and minimum $(1.48 \pm 0.001 \mathrm{mg} / \mathrm{g})$ at $30 \mathrm{~min}$. Likewise trend was observed for TF2A, TF2B \& TF3, among the solvents highest ratio in ethanolic fractions and minimum in water and among time intervals maximum in $60 \mathrm{~min}$ and minimum in 30 min (Fig. 1). 
Table 1 Extraction yield of theaflavin and thearubigins

\begin{tabular}{|c|c|c|c|c|}
\hline \multirow[t]{2}{*}{ Solvents } & \multicolumn{3}{|l|}{ Time } & \multirow[t]{2}{*}{ Means } \\
\hline & $30 \mathrm{~min}$ & $60 \mathrm{~min}$ & $90 \mathrm{~min}$ & \\
\hline \multicolumn{5}{|c|}{ Theaflavin ( $\mathrm{g} / 100 \mathrm{~g}$ black tea) } \\
\hline Ethanol & $3.11 \pm 0.20$ & $4.05 \pm 0.19$ & $3.12 \pm 0.10$ & $3.42 \pm 0.27 a$ \\
\hline Methanol & $2.05 \pm 0.16$ & $3.25 \pm 0.15$ & $3.01 \pm 0.08$ & $2.77 \pm 0.25 b$ \\
\hline \multirow[t]{2}{*}{ Water } & $1.99 \pm 0.04$ & $2.95 \pm 0.19$ & $2.02 \pm 0.04$ & $2.32 \pm 0.13 c$ \\
\hline & $2.38 \pm 0.1 c$ & $3.41 \pm 0.1 a$ & $2.71 \pm 0.1 b$ & \\
\hline \multicolumn{5}{|c|}{ Thearubigins ( $\mathrm{g} / 100 \mathrm{~g}$ black tea) } \\
\hline Ethanol & $12.11 \pm 0.20$ & $15.32 \pm 0.19$ & $12.12 \pm 0.10$ & $13.18 \pm 1.07 a$ \\
\hline Methanol & $11.05 \pm 0.16$ & $13.25 \pm 0.15$ & $12.01 \pm 0.08$ & $12.10 \pm 1.05 b$ \\
\hline \multirow[t]{2}{*}{ Water } & $8.99 \pm 0.04$ & $10.95 \pm 0.19$ & $9.32 \pm 0.04$ & $9.75 \pm 0.42 c$ \\
\hline & $10.71 \pm 0.4 b$ & $13.17 \pm 0.5 a$ & $11.15 \pm 0.9 c$ & \\
\hline
\end{tabular}

Values are mean \pm SD. Values in same column within each parameter with different letters were significantly different from each other $(p \leq 0.05)$

\section{In vitro antioxidant capacity (lipid peroxidation indicators)}

Antioxidant indices of isolated theaflavins \& thearubigins showed significant effect of solvents and time intervals for $\mathrm{DPPH}(p \geq 0.001)$, ß-carotene $(p \geq 0.004)$ and FRAP $(p \geq 0.000)$ whilst non-significant differences $(p \geq 0.185)$ were observed for glucose diffusion. Means for $\mathrm{DPPH}$ in theaflavin and thearubigins indicated highest activity in ethanolic extract $83.27 \pm 1.23$ \& $68.72 \pm 3.61 \%$, respectively followed by methanol and water. For the time factor, the highest $\mathrm{DPPH}$ activity of theaflavin was $82.69 \pm 5.10 \%$ at $60 \mathrm{~min}$ whilst $78.03 \pm 4.31 \& 75.89 \pm 3.92 \%$ at 90 and $30 \mathrm{~min}$, respectively. Similarly, thearubigins also exhibited highest DPPH activity at $60 \mathrm{~min}$ (Table 2).

Likewise, highest $ß$-carotene activity of theaflavin and thearubigins were observed in ethanolic extract and at 60 min time interval. Likewise, The FRAP values for theaflavin and thearubigins were detected highest in ethanolic extract and at $60 \mathrm{~min}$. The highest glucose diffusion was noticed in ethanolic extract of theaflavin $(91.74 \pm 4.16 \%)$ followed by the methanolic (89.96 \pm $2.31 \%)$ and water extract $(87.02 \pm 3.12 \%)$. Likewise, in thearubigins the values for this parameter in respective extracts were $87.71 \pm 6.12,84.92 \pm 6.42$ and 83.02 $\pm 7.12 \%$. Considering time factor, highest glucose diffusion was reported at $60 \mathrm{~min}$ for the both parameters (Table 3).

\section{Biological assay Weight gain}

The Mean values regarding body weights of experiments rats showed significant effect $(p \geq 0.001)$ of experimental diets on weight in both control and renal malfunctional rats and recorded values for weight in renal malfunctional rats at the termination of study were $213.10 \pm 6.11$ \& $213.73 \pm 8.12, \quad 217.74 \pm 5.61 \quad \& \quad 220.52 \pm 9.26$ and $214.17 \pm 4.25 \& 215.73 \pm 6.23 \mathrm{~g} /$ rat for $\mathrm{T}_{1} \mathrm{~T}_{2}$ and $\mathrm{T}_{3}$, respectively (Table 4 ).

\section{Lipid profile}

The prepared diets caused significant $(p \geq 0.000)$ effect on serum cholesterol level of rats, highest cholesterol level was observed in $\mathrm{T}_{0}(86.31 \pm 4.63 \mathrm{mg} / \mathrm{dL})$ that significantly reduced in $\mathrm{T}_{1}(81.14 \pm 2.12 \mathrm{mg} / \mathrm{dL})$ trailed by $\mathrm{T}_{3}(82.29 \pm 4.25 \mathrm{mg} / \mathrm{dL})$ and $\mathrm{T}_{2}(82.99 \pm 5.63 \mathrm{mg} / \mathrm{dL})$. In contrary, the tested diets imparted non-significant $(p \geq 0.091)$ enhancement in HDL levels of study animals. In this context, $\mathrm{T}_{0}$ drink consuming group exhibited least HDL value as $38.54 \pm 2.36 \mathrm{mg} / \mathrm{dL}$, respectively that elevated non-significantly to $39.70 \pm 2.32,38.92 \pm 1.09$ and $39.64 \pm 1.56 \mathrm{mg} / \mathrm{dL}$ in $\mathrm{T}_{1}, \mathrm{~T}_{2}$ and $\mathrm{T}_{3}$ groups, respectively. As for as LDL levels were concern, the tested diets caused momentous $(p \geq 0.000)$ decline on this trait. The maximum LDL was noticed in $\mathrm{T}_{0}$ that reduced substantially to in $T_{1}, T_{2}$ and $T_{3}$, correspondingly. Triglycerides

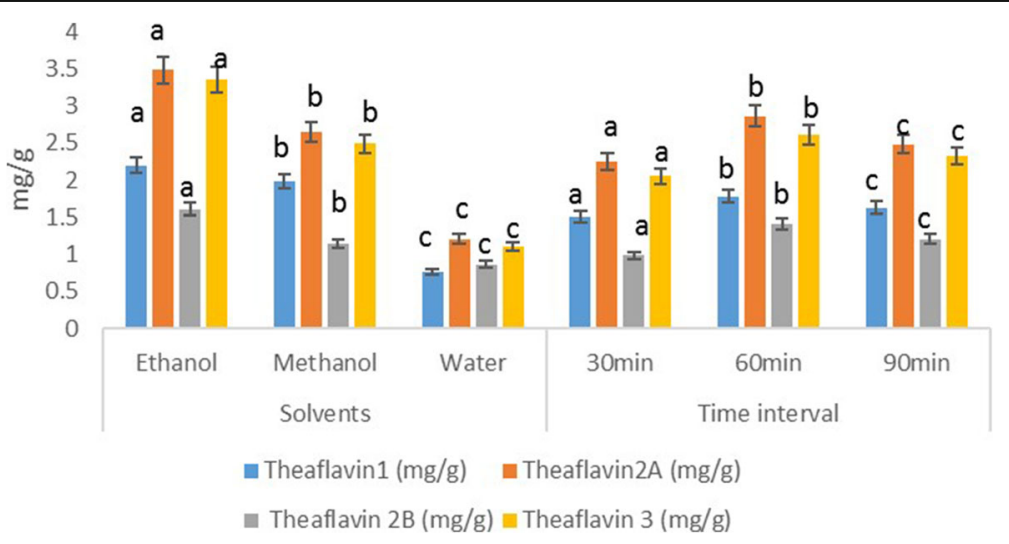

Fig. 1 Absolute values for different isolated theaflavin fractions characterize through reverse phase HPLC in mg/g. Three solvents and time intervals were applied, and comparison were made between solvents and time intervals. Values with different letters were significantly different from each other $(p \leq 0.05)$ 
Table 2 Antioxidant indices of isolated theaflavin and thearubigins

\begin{tabular}{|c|c|c|c|c|}
\hline \multirow[t]{2}{*}{ Solvents } & \multicolumn{3}{|l|}{ Time } & \multirow[t]{2}{*}{ Means } \\
\hline & $30 \mathrm{~min}$ & $60 \mathrm{~min}$ & $90 \mathrm{~min}$ & \\
\hline \multicolumn{5}{|c|}{ DPPH activity (theaflavin)\% } \\
\hline Ethanol & $80.21 \pm 2.31$ & $87.51 \pm 4.21$ & $82.11 \pm 5.91$ & $83.27 \pm 1.23 a$ \\
\hline Methanol & $75.10 \pm 2.60$ & $81.08 \pm 4.30$ & $78.03 \pm 3.60$ & $78.08 \pm 3.74 b$ \\
\hline \multirow[t]{2}{*}{ Water } & $72.37 \pm 3.12$ & $79.49 \pm 4.92$ & $75.97 \pm 4.92$ & $75.94 \pm 2.65 c$ \\
\hline & $75.89 \pm 3.92 \mathrm{C}$ & $82.69 \pm 5.10 a$ & $78.03 \pm 4.31 b$ & \\
\hline \multicolumn{5}{|c|}{ DPPH activity (thearubigins)\% } \\
\hline Ethanol & $62.58 \pm 3.21$ & $74.26 \pm 1.90$ & $69.33 \pm 4.01$ & $68.72 \pm 3.61 a$ \\
\hline Methanol & $60.75 \pm 3.26$ & $63.26 \pm 1.42$ & $61.03 \pm 1.36$ & $61.68 \pm 2.69 b$ \\
\hline \multirow[t]{2}{*}{ Water } & $58.18 \pm 4.32$ & $62.03 \pm 1.93$ & $60.13 \pm 3.02$ & $60.11 \pm 1.36 b$ \\
\hline & $60.50 \pm 2.36 c$ & $66.51 \pm 1.32 a$ & $63.49 \pm 2.13 b$ & \\
\hline \multicolumn{5}{|c|}{ ß-carotene (theaflavin)\% } \\
\hline Ethanol & $63.16 \pm 2.31 c$ & $73.23 \pm 3.60 \mathrm{a}$ & $69.85 \pm 3.42 b$ & $68.74 \pm 4.31 \mathrm{a}$ \\
\hline Methanol & $60.15 \pm 3.62 e$ & $67.35 \pm 2.91 d$ & $65.12 \pm 4.13 d$ & $64.20 \pm 4.72 b$ \\
\hline \multirow[t]{2}{*}{ Water } & $59.61 \pm 4.12 h$ & $64.16 \pm 3.12 \mathrm{~g}$ & $61.04 \pm 1.94 f$ & $61.27 \pm 2.30 c$ \\
\hline & $62.61 \pm 3.12 c$ & $68.91 \pm 2.42 a$ & $65.33 \pm 4.22 b$ & \\
\hline \multicolumn{5}{|c|}{ B-carotene (thearubigins)\% } \\
\hline Ethanol & $60.16 \pm 2.31 c$ & $70.23 \pm 2.81 \mathrm{a}$ & $66.85 \pm 3.10 b$ & $63.74 \pm 1.22 \mathrm{a}$ \\
\hline Methanol & $58.15 \pm 1.52 \mathrm{e}$ & $68.35 \pm 2.33 d$ & $62.12 \pm 4.31 d$ & $62.87 \pm 3.20 b$ \\
\hline \multirow[t]{2}{*}{ Water } & $56.61 \pm 2.90 \mathrm{~h}$ & $65.16 \pm 1.92 \mathrm{~g}$ & $61.04 \pm 3.62 f$ & $60.93 \pm 4.16 b$ \\
\hline & $59.30 \pm 3.13 c$ & $67.91 \pm 2.31 \mathrm{a}$ & $63.33 \pm 4.23 b$ & \\
\hline
\end{tabular}

Values are mean $\pm S D$. Values in same column within each parameter with different letters were significantly different from each other $(p \leq 0.05)$

values for $\mathrm{T}_{0}, \mathrm{~T}_{1}, \mathrm{~T}_{2}$ and $\mathrm{T}_{3}$ differed non-momentously $(p \geq 0.128)$ i.e. $67.15 \pm 4.20,64.96 \pm 5.15,65.20 \pm 4.12$ and $65.13 \pm 2.12 \mathrm{mg} / \mathrm{dL}$ (Table 4). Likewise trend was observed for normal experimental rats, all the experimental diets caused significant impact on total cholesterol and LDL as compared to control.

\section{Glucose \& Insulin Levels}

Mean values showed significant $(p \geq 0.000)$ impact of experimental diets on blood glucose levels of tested groups. In renal malfunctional rats, the highest glucose level $89.18 \pm 6.14$ in $\mathrm{T}_{0}$ group however, black tea polyphenols supplemented diets lowered the glucose value to $84.70 \pm$ $6.13,85.60 \pm 3.20$ and $83.98 \pm 7.14 \mathrm{mg} / \mathrm{dL}$ in $\mathrm{T}_{1}, \mathrm{~T}_{2}$ and $\mathrm{T}_{3}$ groups, correspondingly. Likewise, insulin also varied significantly $(p \geq 0.004)$ minimum insulin values $7.76 \pm 0.22$ $\mu \mathrm{U} / \mathrm{mL}$ were observed in $\mathrm{T}_{0}$ whilst highest level $8.11 \pm$ $0.12 \mu \mathrm{U} / \mathrm{mL}$ in $\mathrm{T}_{3}$ followed by $8.06 \pm 0.41 \mu \mathrm{U} / \mathrm{mL}$ in $\mathrm{T}_{1}$ and $7.96 \pm 0.52 \mu \mathrm{U} / \mathrm{mL}$ in $\mathrm{T}_{2}$ (Table 4).

\section{Serum Urea \& Creatinine levels}

The means in Table 4 regarding the serum urea \& creatinine levels reveled that theaflavin and thearubigins supplemented diets divulged significant $(p \geq 0.001 \& p \geq$ 0.000 , respectively) impact on these traits however, the diet supplemented with both theaflavin and thearubigins caused maximum effect in comparison with others. The highest urea level $37.83 \pm 2.46$ was recorded in $\mathrm{T}_{0}$ that suppressed to $33.44 \pm 1.45,34.09 \pm 2.56$ and $34.95 \pm$ $2.91 \mathrm{mg} / \mathrm{dL}$ in $\mathrm{T}_{3}, \mathrm{~T}_{1}$ and $\mathrm{T}_{2}$ groups. Likewise, highest creatinine level $1.15 \pm 0.03 \mathrm{mg} / \mathrm{dL}$ was recorded in $\mathrm{T}_{0}$ group (control drink) that significantly suppressed to $1.04 \pm 0.05 \mathrm{mg} / \mathrm{dL}$ in $\mathrm{T}_{3}$ (drink containing theaflavin +thearubigins), $1.08 \pm 0.01 \mathrm{mg} / \mathrm{dL}$ in $\mathrm{T}_{1}$ (drink containing theaflavin) and $1.09 \pm 0.02 \mathrm{mg} / \mathrm{dL}$ in $\mathrm{T}_{2}$ (drink containing thearubigins).

\section{Antioxidant status}

$\mathrm{T}_{0}$ group showed decreased glutathione content $43.12 \pm$ $3.01 \mathrm{mg} / \mathrm{L}$ that momentously $(p \geq 0.001)$ enhanced to $46.19 \pm 2.56,44.91 \pm 4.14$ and $47.87 \pm 4.12 \mathrm{mg} / \mathrm{L}$ in $\mathrm{T}_{1}$, $\mathrm{T}_{2}$ and $\mathrm{T}_{3}$ groups. Similar significant $(p \geq 0.000)$ effect of experimental diets was observed for MDA, the recorded values for this trait in T0 was $8.01 \pm 0.21$ that differed significantly in T1, T2 and T3 by $6.78 \pm 0.24,7.55 \pm 0.01$ and $6.95 \pm 0.4 \mathrm{mmol} / \mathrm{L}$ (Table 4). Again, the more pronounced effect was observed for T3 (drink containing theaflavin+thearubigins) followed by T1 (drink containing theaflavin) \& T2 (drink containing thearubigins).

\section{Liver function tests}

Mean values in Table 4 showed pronounced effect of experimental diets on liver function enzymes. In this scenario, ALT value in $\mathrm{T}_{0}(49.06 \pm 3.01 \mathrm{IU} / \mathrm{L})$ was significantly $((p \geq 0.001))$ varied in $\mathrm{T}_{1} \mathrm{~T}_{2}$ and $\mathrm{T}_{3}$ groups with mean values $48.50 \pm 2.42,49.12 \pm 2.13$ and $46.38 \pm$ $2.45 \mathrm{IU} / \mathrm{L}$. Moreover, $\mathrm{T}_{0}$ group showed maximum AST level $105.27 \pm 5.14 \mathrm{IU} /$ Lthat reduced substantially $((p \geq$ $0.002)$ in $\mathrm{T}_{1}(101.68 \pm 9.12 \mathrm{IU} / \mathrm{L}), \mathrm{T}_{2}(103.00 \pm 9.02 \mathrm{IU} / \mathrm{L})$ and $\mathrm{T}_{3}(109.01 \pm 9.45 \mathrm{IU} / \mathrm{L})$. Likewise, ALP level in $\mathrm{T}_{0}$ $(196.89 \pm 17.23 \mathrm{IU} / \mathrm{L})$ was significantly $((p \geq 0.001))$ higher than that of $\mathrm{T}_{1}(177.89 \pm 15.20 \mathrm{IU} / \mathrm{L}), \mathrm{T}_{2}(180.90$ $\pm 13.25 \mathrm{IU} / \mathrm{L})$ and $\mathrm{T}_{3}(167.68 \pm 9.62 \mathrm{IU} / \mathrm{L})$.

\section{Hematological analysis}

Mean values for heamatological indices indicated non-significant differences due to treatments on red and white cell indices. The recorded RBCs values were 6.13 $\pm 0.22,6.21 \pm 0.82,6.15 \pm 0.25$ and $6.39 \pm 0.63$ cells $/ \mathrm{pL}$ in $\mathrm{T}_{0}, \mathrm{~T}_{1}, \mathrm{~T}_{2}$ and $\mathrm{T}_{3}$, respectively. Mean Hb level in $\mathrm{T}_{0}, \mathrm{~T}_{1}$, $\mathrm{T}_{2}$ and $\mathrm{T}_{3}$ were $10.88 \pm 0.71,11.15 \pm 0.61,10.98 \pm 0.81$ and $11.20 \pm 0.71 \mathrm{~g} / \mathrm{L}$, respectively. Moreover, the recorded hematocrit value for $\mathrm{T}_{0}(36.79 \pm 1.52 \%)$ was improved non-significantly in $\mathrm{T}_{1}, \mathrm{~T}_{2}$ and $\mathrm{T}_{3}$ groups as $37.25 \pm 2.71,36.99 \pm 2.12$ and $37.03 \pm 2.81 \%$, respectively. Likewise, mean MCV values for $\mathrm{T}_{0}, \mathrm{~T}_{1}, \mathrm{~T}_{2}$ and $\mathrm{T}_{3}$ were $49.96 \pm 2.48, \quad 51.03 \pm 3.82, \quad 50.92 \pm 3.97$ and $51.65 \pm$ 
Table 3 FRAP and Glucose diffusion of isolated theaflavin and thearubigins

\begin{tabular}{|c|c|c|c|c|}
\hline \multirow[t]{2}{*}{ Solvents } & \multicolumn{3}{|l|}{ Time } & \multirow[t]{2}{*}{ Means } \\
\hline & $30 \mathrm{~min}$ & $60 \mathrm{~min}$ & $90 \mathrm{~min}$ & \\
\hline \multicolumn{5}{|c|}{$\begin{array}{l}\text { FRAP (theaflavin) } \\
\mu \mathrm{mol} \text { Fe } 2^{+} / \mathrm{g}\end{array}$} \\
\hline Ethanol & $811.67 \pm 10.21$ & $958.33 \pm 8.48$ & $799.33 \pm 12.31$ & $856.44 \pm 9.06 a$ \\
\hline Methanol & $698.67 \pm 10.36$ & $704.00 \pm 8.65$ & $658.67 \pm 11.32$ & $687.11 \pm 12.03 b$ \\
\hline \multirow[t]{2}{*}{ Water } & $489.67 \pm 10.56$ & $612.25 \pm 8.23$ & $586.67 \pm 13.01$ & $562.86 \pm 11.01 \mathrm{C}$ \\
\hline & $666.67 \pm 10.54 c$ & $758.19 \pm 8.21 a$ & $681.55 \pm 9.06 b$ & \\
\hline \multicolumn{5}{|c|}{$\begin{array}{l}\text { FRAP (thearubigins) } \\
\mu \mathrm{mol} F e 2^{+} / \mathrm{g}\end{array}$} \\
\hline Ethanol & $690.02 \pm 1.23$ & $845.01 \pm 7.45$ & $701.33 \pm 12.23$ & $745.44 \pm 8.21 a$ \\
\hline Methanol & $538.67 \pm 1.56$ & $665.00 \pm 7.49$ & $591.67 \pm 11.32$ & $598.44 \pm 11.20 b$ \\
\hline \multirow[t]{2}{*}{ Water } & $429.67 \pm 10.23$ & $537.33 \pm 7.52$ & $503.67 \pm 10.25$ & $490.22 \pm 12.20 c$ \\
\hline & $552.70 \pm 10.21 \mathrm{c}$ & $682.40 \pm 12.23 a$ & $598.89 \pm 9.12 b$ & \\
\hline \multicolumn{5}{|c|}{ Glucose diffusion (theaflavin)\% } \\
\hline Ethanol & $90.37 \pm 3.60$ & $95.99 \pm 6.34$ & $90.88 \pm 4.13$ & $91.74 \pm 4.16$ \\
\hline Methanol & $89.87 \pm 4.21$ & $93.69 \pm 4.21$ & $89.22 \pm 6.12$ & $89.96 \pm 2.31$ \\
\hline \multirow[t]{2}{*}{ Water } & $87.30 \pm 2.62$ & $90.36 \pm 5.32$ & $88.40 \pm 3.21$ & $87.02 \pm 3.12$ \\
\hline & $89.18 \pm 5.20$ & $93.34 \pm 3.12$ & $89.50 \pm 4.13$ & \\
\hline \multicolumn{5}{|c|}{ Glucose diffusion (thearubigins)\% } \\
\hline Ethanol & $85.27 \pm 2.3$ & $89.99 \pm 2.9$ & $87.88 \pm 4.2$ & $87.71 \pm 6.12$ \\
\hline Methanol & $83.87 \pm 1.3$ & $87.69 \pm 3.2$ & $83.22 \pm 3.6$ & $84.92 \pm 6.42$ \\
\hline \multirow[t]{2}{*}{ Water } & $81.30 \pm 3.6$ & $85.36 \pm 2.9$ & $82.40 \pm 4.2$ & $83.02 \pm 7.12$ \\
\hline & $83.48 \pm 4.32$ & $87.68 \pm 4.13$ & $84.50 \pm 6.34$ & \\
\hline
\end{tabular}

Values are mean \pm SD. Values in same column within each parameter with different letters were significantly different from each other ( $p \leq 0$. 05 )

$3.30 \mathrm{fl}$, respectively. Similarly, the mean WBCs in $\mathrm{T}_{0}$ were $17.29 \pm 0.58$ cells $/ \mathrm{nL}$ that non-significantly decreased to $16.99 \pm 0.49,17.26 \pm 0.65$ and $16.85 \pm 0.35$ cells $/ \mathrm{nL}$, respectively in tested groups. Likewise, means for Neutrophils in $\mathrm{T}_{0}, \mathrm{~T}_{1}, \mathrm{~T}_{2}$, and $\mathrm{T}_{3}$ were $62.25 \pm 1.28$, $63.85 \pm 2.82,62.45 \pm 3.25$ and $64.63 \pm 2.63 \%$, respectively. Mean monocytes values for $\mathrm{T}_{0}, \mathrm{~T}_{1}, \mathrm{~T}_{2}$ and $\mathrm{T}_{3}$ groups were $5.29 \pm 0.21, \quad 5.35 \pm 0.22, \quad 5.41 \pm 0.25$ and $5.65 \pm$ $0.63 \%$, respectively. In study IV, values for Lymphocytes were $33.92 \pm 1.21,35.25 \pm 1.82,34.91 \pm 1.25$ and $35.29 \pm$ $1.63 \%$ in $\mathrm{T}_{0}, \mathrm{~T}_{1}, \mathrm{~T}_{2}$ and $\mathrm{T}_{3}$ group, respectively (Fig. 2).

\section{Discussion}

In the current study we first time examined the synergistic role of isolated theaflavins and thearubigins against the indicators for lipid peroxidation both in in vitro and in vivo by utilizing excessive arginine induced renal malfunctional rats. The hall mark of the research is the optimization of these bioactive moieties isolation through different solvents and time intervals. The outcomes of study indicated that the isolation was affected by nature of solvent and intervals of extraction. The results clearly depicted that the extraction yield was associated with type of solvents and extraction time. In the current study, the significant effect of solvents on polyphenols recovery are also supported by the work of $[28,29]$, observed method of extraction and time of extraction are the considerate factors in this context. Extraction time and yield have a linear association however, nature of the compound is a detrimental factor for optimum recovery. The lower isolate recovery at elevated extraction time beyond $60 \mathrm{~min}$ might be due to thermal degradation. The high temperature may trigger the early decomposition of polyphenols resulting reduction in optimum recovery. Nevertheless, extraction at lower temperature required more time for inclusive isolation thereby exerting less harm to the polyphenols.

The antioxidant indices are the good indicators for compounds ability to provide protection against lipid peroxidation and also provide evidence for its in vivo therapeutic potential. The higher DPPH activity of theaflavins as compared to thearubigins is might be due to benzotropolone skeleton formation during co-oxidation of catechins, one with a vic-trihydroxy moiety and the other with an ortho-dihydroxy structure. Moreover, chemical structure of theaflavin contains two A-rings of flavanols linked by fused seven-member ring. These structural features provide more interaction sites to free radicals. 
Table 4 Effect of theaflavin and thearubigins and their combination based intervention on selected traits of normal and renal malfunctional rats at the termination of the study (56th day)

\begin{tabular}{|c|c|c|c|c|}
\hline Parameters & $\begin{array}{l}\text { Base line values } \\
(n=1)\end{array}$ & Treatments & $\begin{array}{l}\text { Post treatment values at } \\
\text { termination of study } \\
\text { Control Study (Normal Rats) }\end{array}$ & $\begin{array}{l}\text { Post treatment values at } \\
\text { termination of study } \\
\text { Arginine induced renal } \\
\text { malfunctional rats }\end{array}$ \\
\hline \multirow{4}{*}{$\begin{array}{l}\text { Body weight } \\
\text { (at the termination of study) }\end{array}$} & \multirow[t]{4}{*}{$128 \pm 10.25$} & T0 & $224.18 \pm 10.25 a$ & $223 \pm 9.61 a$ \\
\hline & & $\mathrm{T} 1$ & $212.14 \pm 9.23 d$ & $213.10 \pm 6.11 c$ \\
\hline & & $\mathrm{T} 2$ & $216.41 \pm 8.56 b$ & $217.74 \pm 5.61 b$ \\
\hline & & T3 & $213.12 \pm 9.22 c$ & $214.17 \pm 4.25 c$ \\
\hline \multirow[t]{4}{*}{$\mathrm{TC}(\mathrm{mg} / \mathrm{dL})$} & \multirow[t]{4}{*}{$77.80 \pm 3.56$} & T0 & $85.14 \pm 4.12 \mathrm{a}$ & $86.31 \pm 4.63 a$ \\
\hline & & $\mathrm{T} 1$ & $82.13 \pm 3.25 c$ & $81.14 \pm 2.12 c$ \\
\hline & & $\mathrm{T} 2$ & $84.15 \pm 2.212 b$ & $82.99 \pm 5.63 b$ \\
\hline & & T3 & $83.1 \pm 3.14 c$ & $82.29 \pm 4.25 b$ \\
\hline \multirow[t]{4}{*}{ LDL-C (mg/dL) } & \multirow[t]{4}{*}{$26.56 \pm 3.56$} & T0 & $27.10 \pm 0.96 a$ & $33.36 \pm 2.13 a$ \\
\hline & & $\mathrm{T} 1$ & $26.01 \pm 1.01 c$ & $30.94 \pm 1.22 \mathrm{C}$ \\
\hline & & $\mathrm{T} 2$ & $26.65 \pm 0.95 b$ & $32.20 \pm 3.61 b$ \\
\hline & & T3 & $26.30 \pm 1.02 b$ & $31.49 \pm 2.81 b$ \\
\hline \multirow[t]{4}{*}{$\mathrm{HDL}-\mathrm{C}(\mathrm{mg} / \mathrm{dL})$} & \multirow[t]{4}{*}{$32.56 \pm 3.56$} & T0 & $38.45 \pm 1.1$ & $38.54 \pm 2.36$ \\
\hline & & $\mathrm{T} 1$ & $39.21 \pm 0.96$ & $39.70 \pm 2.32$ \\
\hline & & $\mathrm{T} 2$ & $39.01 \pm 0.85$ & $38.92 \pm 1.09$ \\
\hline & & T3 & $39.14 \pm 0.89$ & $39.64 \pm 1.56$ \\
\hline \multirow[t]{4}{*}{ TG (mg/dL) } & \multirow[t]{4}{*}{$58.26 \pm 3.56$} & & $69.45 \pm 1.20 \mathrm{a}$ & $67.15 \pm 4.20$ \\
\hline & & $\mathrm{T} 1$ & $67.12 \pm 1.14 c$ & $64.96 \pm 5.15$ \\
\hline & & $\mathrm{T} 2$ & $68.01 \pm 1.05 b$ & $65.20 \pm 4.12$ \\
\hline & & T3 & $67.65 \pm 1.08 c$ & $65.13 \pm 2.12$ \\
\hline \multirow[t]{4}{*}{ Glucose (mg/dL) } & \multirow[t]{4}{*}{$79.63 \pm 3.72$} & T0 & $85.65 \pm 2.2 \mathrm{a}$ & $89.18 \pm 6.14 a$ \\
\hline & & $\mathrm{T} 1$ & $83.15 \pm 1.96 b$ & $84.70 \pm 6.13 b$ \\
\hline & & $\mathrm{T} 2$ & $83.69 \pm 1.12 b$ & $85.60 \pm 3.20 b$ \\
\hline & & T3 & $82.38 \pm 1.23 c$ & $83.98 \pm 7.14 b$ \\
\hline \multirow[t]{4}{*}{ Insulin $\mu \mathrm{U} / \mathrm{Ml}$} & \multirow[t]{4}{*}{$6.23 \pm 0.56$} & T0 & $8.25 \pm 0.01 b$ & $7.76 \pm 0.22 b$ \\
\hline & & $\mathrm{T} 1$ & $8.91 \pm 0.25 a$ & $8.06 \pm 0.41 a$ \\
\hline & & $\mathrm{T} 2$ & $8.80 \pm 0.31 b$ & $7.96 \pm 0.52 \mathrm{ab}$ \\
\hline & & T3 & $8.99 \pm 0.21 a$ & $8.11 \pm 0.12 \mathrm{a}$ \\
\hline \multirow[t]{4}{*}{ Serum Urea mg/Dl } & \multirow[t]{4}{*}{$32.56 \pm 1.03$} & T0 & $26.14 \pm 1.01 a$ & $37.83 \pm 2.46 a$ \\
\hline & & T1 & $25.96 \pm 1.04 b$ & $34.09 \pm 2.56 b$ \\
\hline & & $\mathrm{T} 2$ & $26.01 \pm 0.96 a$ & $34.95 \pm 2.91 b$ \\
\hline & & T3 & $25.78 \pm 0.88 b$ & $33.44 \pm 1.45 c$ \\
\hline \multirow[t]{4}{*}{ Serum creatinine (mg/dL) } & \multirow[t]{4}{*}{$1.01 \pm 0.02$} & T0 & $0.719 \pm 0.01$ & $1.15 \pm 0.03 a$ \\
\hline & & $\mathrm{T} 1$ & $0.715 \pm 0.02$ & $1.08 \pm 0.01 b$ \\
\hline & & $\mathrm{T} 2$ & $0.716 \pm 0.01$ & $1.09 \pm 0.021 b$ \\
\hline & & T3 & $0.701 \pm 0.03$ & $1.04 \pm 0.05 c$ \\
\hline \multirow[t]{4}{*}{ Serum glutathione (mg/L) } & \multirow[t]{4}{*}{$42.32 \pm 1.02$} & T0 & $50.52 \pm 1.01 b$ & $43.12 \pm 3.01 c$ \\
\hline & & $\mathrm{T} 1$ & $52.99 \pm 1.45 a b$ & $46.19 \pm 2.56 b$ \\
\hline & & $\mathrm{T} 2$ & $52.14 \pm 1.21 \mathrm{ab}$ & $44.91 \pm 4.14 b c$ \\
\hline & & T3 & $53.01 \pm 1.24 a$ & $47.87 \pm 4.12 \mathrm{a}$ \\
\hline Malonialdehyde (MDA) & $6.23 \pm 0.59$ & T0 & $7.85 \pm 0.14 a$ & $8.01 \pm 0.21 \mathrm{a}$ \\
\hline
\end{tabular}


Table 4 Effect of theaflavin and thearubigins and their combination based intervention on selected traits of normal and renal malfunctional rats at the termination of the study (56th day) (Continued)

\begin{tabular}{|c|c|c|c|c|}
\hline Parameters & $\begin{array}{l}\text { Base line values } \\
(n=1)\end{array}$ & Treatments & $\begin{array}{l}\text { Post treatment values at } \\
\text { termination of study } \\
\text { Control Study (Normal Rats) }\end{array}$ & $\begin{array}{l}\text { Post treatment values at } \\
\text { termination of study } \\
\text { Arginine induced renal } \\
\text { malfunctional rats }\end{array}$ \\
\hline & & $\mathrm{T} 1$ & $6.23 \pm 0.18 b$ & $6.78 \pm 0.24 c$ \\
\hline & & $\mathrm{T} 2$ & $7.15 \pm 0.12 a$ & $7.55 \pm 0.01 a$ \\
\hline & & T3 & $6.85 \pm 0.13 a b$ & $6.95 \pm 0.42 b$ \\
\hline \multirow[t]{4}{*}{ AST (IU/L) } & $6.23 \pm 0.59$ & T0 & $7.85 \pm 0.14 a$ & $8.01 \pm 0.21 a$ \\
\hline & & T1 & $6.23 \pm 0.18 b$ & $6.78 \pm 0.24 c$ \\
\hline & & $\mathrm{T} 2$ & $7.15 \pm 0.12 a$ & $7.55 \pm 0.01 a$ \\
\hline & & T3 & $6.85 \pm 0.13 a b$ & $6.95 \pm 0.42 b$ \\
\hline \multirow[t]{4}{*}{ ALT(IU/L) } & $6.23 \pm 0.59$ & T0 & $7.85 \pm 0.14 a$ & $8.01 \pm 0.21 a$ \\
\hline & & $\mathrm{T} 1$ & $6.23 \pm 0.18 b$ & $6.78 \pm 0.24 c$ \\
\hline & & $\mathrm{T} 2$ & $7.15 \pm 0.12 a$ & $7.55 \pm 0.01 a$ \\
\hline & & T3 & $6.85 \pm 0.13 a b$ & $6.95 \pm 0.42 b$ \\
\hline \multirow[t]{4}{*}{ ALP(IU/L) } & $6.23 \pm 0.59$ & T0 & $7.85 \pm 0.14 a$ & $8.01 \pm 0.21 a$ \\
\hline & & $\mathrm{T} 1$ & $6.23 \pm 0.18 b$ & $6.78 \pm 0.24 c$ \\
\hline & & $\mathrm{T} 2$ & $7.15 \pm 0.12 a$ & $7.55 \pm 0.01 a$ \\
\hline & & T3 & $6.85 \pm 0.13 \mathrm{ab}$ & $6.95 \pm 0.42 b$ \\
\hline
\end{tabular}

T0: Group rely on Basic Experimental Diet

T1: Group rely on Basic Experimental Diet+ theaflavins supplementation @ $1 \mathrm{~g}$

T2: Group rely on Basic Experimental Diet+ Thearubigins supplementation @ $1 \mathrm{~g}$

T3: Group rely on Basic Experimental Diet+ Supplementation of theaflavins+ thearubigins @ $0.5+0.5 \mathrm{~g}$, respectively

Values are mean \pm SEM $(n=10)$

One way anova was applied to check the overall behavior of the study parameter to elaborate the effect of treatments on selected parameter of rats at the termination of study. To evaluate the differences among the mean LSD test was applied. Values in same column within each parameter with different letters were significantly different from each other $(p \leq 0.05)$

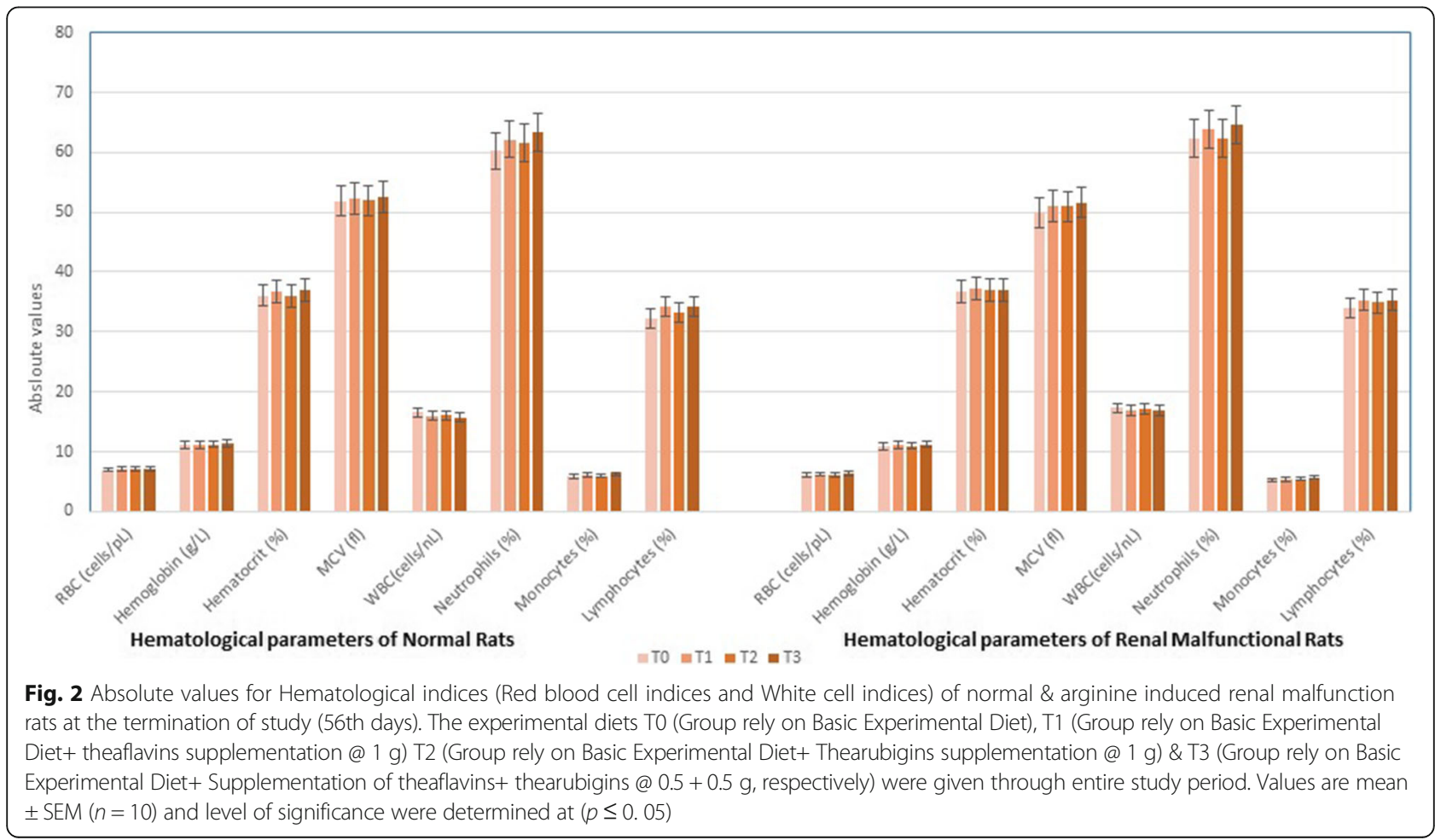


Higher free radical and hydrogen peroxide quenching capacity of theaflavin is might be due to benzotropolone ring however, the ability of individual theaflavin moiety depends upon its gallate structure [30]. The lower DPPH activity of thearubigins as compared to theaflavins is due to the presence of structural differences between theaflavin and thearubigins. The theaflavin holds more galloyl moieties along with hydroxyl groups thus showed higher anti-radical ability [31]. Alongside, theaflavin also exhibited strong FRAP value owing to its ability to quench the generated $\mathrm{Fe}$ (II) free radical.

The higher amount of TF1, TF2, TF2B and TF3 were detected differently in different solvents. The difference is might be as a function of polarity of the solvent and nature of the theaflavin fractions. Moreover, individual theaflavins fraction in tea was dependent upon the plucking season, varietals variations and processing method along with analytical technique [32].

In the current exploration, more potent effect of theaflavin as lipid management drug as compared to its counterparts might be explicated through its ability to diminish the intestinal lipid absorption and pancreatic lipase activity [33]. Fatty acid synthase (FAS) enzyme imbalance is responsible for the initiation of different metabolic related abnormalities and FAS inhibitors can play a pivotal role. Accordingly, theaflavin manage the inhibition of FAS through downregulation of PI-3 K/AKT/ Sp-1 pathway [34]. Black tea polyphenols manage the lipid related abnormalities through different mechanistic routes like accelerating the fecal excretion of fatty acids and sterols, by modulating the satiety, thermogenesis and fat oxidation, stimulating the cellular energy expenditure and interfere with cholesterol micelle solubilization [35]. An array of evidences has proven the ability of black tea polyphenols especially theaflavin to reverse LDL oxidation by scavenging the free radicals, hindering the foam cell formation and deposition Antioxidative action is not solely the route by which tea inhibits LDL level in the subjects; tea polyphenols also have the ability to address this menace with some other mechanistic approaches. One of the key targets is the modulation of adiponectin level [36, 37]. Hypoglycemic ability of black tea is associated with their impact on the modulation of glucose carriers like GLUTs, translocation proteins IR $\beta$, AMPKR and GLUT4 expressions that involved in the maintenance of glucose homeostasis. Oxidative stress induced reduction in the expression of GLUT4 and associated proteins resulting reduction in glucose incorporation in the cells thus amplified the glycemic abnormalities [38, 39]. Among the other mechanistic concerns improvement in the muscle glucose transporters, adipocytes and leptin reductions are the possible mechanisms by which black tea polyphenols perform their action for insulin management [40]. There are established evidences highlighted the therapeutic role of black tea polyphenols against kidney malfunctioning [12]. The continuous ingestion of black tea for a period of 8 weeks caused momentous reduction in blood urea owing to its high antioxidative potential. In a study [41], noticed elevation of urea and creatinine levels in rats fed on high arginine diet due to the production of uremic acid toxins and suppression of certain key hormones. The phenomenon of oxidative stress induced undesirable changes in kidney functionality that can be tackled by black tea polyphenols especially through theaflavin and thearubigins by quenching free radicals. The tea polyphenols modulate the arachidonic acid metabolism, suppressing the prostaglandin (PG), thromboxane A2 and cyclooxygenase expressions of arachidonic acid in microsomes and glomeruli thus helpful in the management of kidney abnormalities $[42,43]$. They inferred that during oxidative stress some morphological abnormalities in glomerulus, capillaries and tubules are produced that can successfully be uplifted by black tea. Earlier [44], explicated that black tea modulates c-reactive proteins and uric acid production that ultimately reduce toxins from kidney, alleviate free radicals and inflammation. It is also worth mentioning that tea polyphenols resulted marked decline in the creatinine level by their action on platelets thus enables kidneys to regain their normal functioning. Moreover, the diuretic effect of black tea enhances renal blood flow, capillary expansion and glomerular filtration. They proposed that improvement in inflammation, sore lesion and deformation in tubules are the leading routes for renal modulating action. The inverse association between glutathione and oxidative stress has been unveiled in many research explorations. There are consolidated evidences in favor of black tea polyphenols capacity to combat oxidative stress by enhancing the activity of glutathione and other antioxidant enzymes. Moreover, it provides assistance through theaflavin and thearubigins to quench the free radicals (hydroxyl and superoxide anions) as a consequence of abnormal oxygen balance in the body. Theaflavin and thearubigins are the proven antioxidant and metal chelators that equally effective in vivo and in vitro models due to their instinct to trap the noxious radicals like superoxide and peroxyl [45]. Additionally, theaflavin and thearubigins assist to quench the hydroxyl radical, ferryl and superoxide radical anion. The majority of the studies elucidated that apart from free radical scavenging and metal chelating abilities. They have potential to activate certain antioxidant enzymes like glutathione-S-transferase (GST), glutathione peroxidase (GPX), superoxide dismutase (SOD) and catalase (CAT) thereby reduce lipid peroxidation. Previous studies showed that black tea polyphenols especially theaflavin have ability to attenuate the process of lipid peroxidation. Structurally, 
theaflavin is composed of vicinal dihydroxy and trihydroxy components and benzotropolone skeleton responsible for free radicals quenching and metal ions chelating potency. The altered hematological markers are the indicators of adverse effect of a diet or drug that ultimately cause multi-dimensional malfunctioning in the body. The abnormalities in both white and red blood cells indices are reported by different scientists during diseases state. They deduced that enhancement in microvescicles formation, production of excessive toxins and membrane oxidations are the possible reasons that induce elevation in white blood cells and decline in hemoglobin, red blood cells and monocytes [46]. In current study, theaflavin and thearubigins administration caused non-significant improvements in abnormal hematological parameters might be due to their antioxidative potential that helpful against oxidative stress.

\section{Conclusions}

It is envisaged from present discussion that theaflavin and thearubigins based dietary intervention has proved effectual to assuage the oxidative stress related maladies. Moreover, extraction conditions also have impact on the yield of these bioactive moieties. Likewise, they imparted significant impact on the indices of lipid peroxidation both in vitro and in vivo thus suitable to tackle oxidative abnormalities. Moreover, it is recommended that in future more sophisticated methods like GS-NEM conjugates by HPLC or GSH recycling method should be adapted for the Gluthathione (GSH) determination to enhance the authenticity of the results. Likewise, human efficacy trial for insulin sensitivity/resistance by different test like HOMA-insulin resistance, QUIKI, and Matsuda should be conducted to unveil the mechanistic concerns.

\footnotetext{
Abbreviations

ALP: Alkaline phosphatase; ALT: Alanine transaminase; AMPK: Activation of activated protein kinase; AST: Aspartate aminotransferase; CKD: Chronic kidney disease; CYP1A1: CYTOCHROME P450, SUBFAMILY I, POLYPEPTIDE 1; FAS: Fatty acid synthase enzyme; GLTU: Glucose transporters; GPX: Glutathione peroxidase; GSH-Px: Glutathione peroxidase; GST: Glutathione-S-transferase; HDL: High density Lipoprotein; IR $\beta$ : Insulin receptor $\beta$ subunit; LDL: Low density Lipoprotein; MDA: Malondialdehyde; OHdG: 8-hydroxy-2' -deoxyguanosine; PG: Prostaglandin; POD: Peroxidase; PPO: Polyphenoloxidase; ROS: Reactive oxygen spices; TC: Total Cholesterol; TFs: Theaflavins; TG: Triglycerides; TRBs: Thearubigins; VLDL: Very low density Lipoprotein
}

\section{Acknowledgements}

The authors are grateful to Higher Education Commission (HEC), Government of Pakistan for their financial support to carry out the present research. The authors are also highly obliged to the Library Department, Government College University Faisalabad (GCUF) and IT Department, HEC for access to journals, books and valuable database.

\section{Funding}

Financial assistance for this study was provided by Higher Education Commission of Pakistan.

\section{Availability of data and materials}

The dataset supporting the conclusions of this article is included within the article.

\section{Authors' contributions}

The contribution of the each author for this manuscript was as follows, Al \& MUA, MI, designed the experimental plan. Al conducted the analysis. Al, MSA, drafted the manuscript and FS \& MS improved the statistical portion of the manuscript. It is also confirmed that all the authors read and approved the final manuscript.

\section{Ethics approval}

Not applicable.

However, The protocol for this biological study involving rats was approved from Departmental ethical committee of GCUF that was in compliance with international standards ERC NO 2121.

\section{Consent for publication}

Not applicable.

\section{Competing interests}

The authors declare that they have no competing interests.

\section{Publisher's Note}

Springer Nature remains neutral with regard to jurisdictional claims in published maps and institutional affiliations.

\section{Author details}

${ }^{1}$ Institute of Home and Food Sciences, Government College University, Faisalabad 38040, Pakistan. ${ }^{2}$ Department of Food Science and Human Nutrition, University of Veterinary and Animal Sciences, Lahore 54000, Pakistan. ${ }^{3}$ University Institute of Diet and Nutritional Sciences, Faculty of Allied Health Sciences, The University Of Lahore-Pakistan, Lahore, Pakistan.

Received: 20 November 2017 Accepted: 28 June 2018

Published online: 18 July 2018

References

1. Wang C, Li Y. Research progress on property and application of theaflavins. Afr J Biotechnol. 2006;5(3):213-8.

2. Sajilata MG, Bajaj PR, Singhal RS. Tea polyphenols as nutraceuticals. Compr Rev Food Sci Food Saf. 2008;7:229-54.

3. Wu C, Xu H, Héritier J, Andlauer W. Determination of catechins and flavonol glycosides in Chinese tea varieties. Food Chem. 2012;132:144-9.

4. Owuor PO, Obanda M, Nyirenda HE, Mphangwe NIK, Wright LP, Apostolides $Z$. The relationship between some chemical parameters and sensory evaluations for plain black tea (Camellia sinensis) produced in Kenya and comparison with similar teas from Malawi and South Africa. Food Chem. 2006;97:644-53.

5. Khan N, Mukhtar H. Tea polyphenols for health promotion. Life Sci. 2007:81:519-33.

6. Alipoor B, Rad AH. A review on the therapeutical effects of tea. Asian J Clin Nutr. 2012;4(1):1-15.

7. Kumar N, Shibata D, Helm J, Coppola D, Malafa M. Green tea polyphenols in the prevention of colon cancer. Front Biosci. 2007;12:2309-15.

8. Lambert JD, Sang S, Yang CS. Biotransformation of green tea polyphenols and the biological activities of those metabolites. Mol Pharm. 2007;4:819-25.

9. Patel R, Maru G. Polymeric black tea polyphenols induce phase II enzymes via Nrf2 in mouse liver and lungs. Free Rad Biol Med. 2008:44:1897-911.

10. Guyton AC, Hall JE. Medical physiology. Compared with (+) control group. Chap. 31 \& 79. 11 th ed; 2006. p. 406. 990 \& 992

11. Ashraf A, El-Megeid J, Allah IZA, Elsadek MF, Moneim YFE. The protective effect of the fortified bread with green tea against chronic renal failure induced by excessive dietary arginine in male albino rats. World J Dairy Food Sci. 2009;4(2):107-17.

12. Xie B, Shi H, Chen $Q$, Ho CT. Antioxident properties of fractions and polyphenol constituents from green, oolong and black teas. Proc Natl Sci Council Rep China. 1993;17(2):77-84.

13. Singleton VL, Orthofer R, Lamuela-Raventos RM. Analysis of total phenols and other oxidation substrates and antioxidants by means of Folin-Ciocalteu reagent. Enzymol. 1999;299:152-78. 
14. Taga MS, Miller EE, Pratt DE. China seeds as source of natural lipid antioxidation. J Am Oil Chem Soc. 1984;61:928-31.

15. Brand-Williams W, Cuvelier ME, Berset C. Use of a free radical method to evaluate antioxidant activity. Lebensm Wiss Technol. 1995:28:25-30.

16. Sun C, Fu J, Chen J, Jiang L, Pan Y. On-line HPLC method for screening of antioxidants against superoxide anion radical from complex mixtures. J Sci. 2010;33:1018-23.

17. Gallagher AM, Flatt PR, Duffy G, Abdel-Wahab YHA. The effects of traditional antidiabetic plants on in vitro glucose diffusion. Nutr Res. 2003;23:413-24.

18. Adedapo A, Mogbojuri O, Emikpe B. Safety evaluations of the aqueous extract of the leaves of Moringa oleifera in rats. J Med Plant. 2009;3:586-91.

19. Alshatwi AA, Al-Obaaid MA, Al-Sedairy SA, Al-Assaf AH, Zhang J, Lei KY. Tomato powder is more protective than lycopene supplement against lipid peroxidation in rats. J Nutr Res. 2010;30:66-73.

20. Thomas L, Labor U. Enzymateischer kinetischer colorimetrischer test (GOD-PAP). Diagnose. 1992;4:169.

21. Ahn J, Choi W, Kim S, Ha T. Anti-diabetic effect of watermelon (Citrullus vulgaris Schrad) on Streptozotocin-induced diabetic mice. Food Sci Biotechnol. 2011;20(1):251-4.

22. Jacobs DS, DeMott WR, Grady HJ, Horvat RT, Huestis DW, Kasten BL. Laboratory test handbook. 4th ed. Cleveland: Lexi-comp Inc., Hudson; 1996.

23. Feng $\mathrm{CH}$, Huang HY, Lu CY. Quantitation of the glutathione in human peripheral blood by matrix assisted laser desorption ionization time-of-flight mass spectrometry coupled with micro-scale derivatization. Anal Chem. 2011;690(2):209-14.

24. Huang CS, Yin MC, Chiu LC. Antihyperglycemic and antioxidative potential of Psidium guajava fruit instreptozotocin-induced diabetic rats. Food Chem. 2011:49(9):2189-95.

25. Ohakawa H, Oshishi N, Yagi K. Assay for lipid peroxidation in animal tissue by Thiobarbituric acid reaction. Anal Biochem. 1979;75:351-8.

26. AlHaj M, Kazzam E, Nagelkerke NJ, Nyberg F, Nicholls MG, Adem A. Effect of dehydration in the presence and absence of the angiotensin receptor blocker losartan on blood constituents in the camel. J Med Sci. 2011;4(2):73-8.

27. Yang Z, Jie G, Dong F, Xua Y, Watanabe N, Tu Y. Radical-scavenging abilities and antioxidant properties of theaflavins and their gallate esters in H2O2-mediated oxidative damage system in the HPF-1 cells. Toxicology. 2008;22:1250-6.

28. Krishnan R, Maru GB. Isolation and analyses of polymeric polypheno fractions from black tea. Food Chem. 2006;94:331-40.

29. Imran A, Sadiq Butt M, Saeed F, Sajid Arshad M, Sultan T, Sohaib M. Effect of different time-solvent interactions on polyphenol content of milky tea. J Food Process Preserv. 2017:41(4):e13039.

30. Yang Z, Tu Y, Xia H, Jie G, Chen X, He P. Suppression of free-radicals and protection against $\mathrm{H} 2 \mathrm{O} 2$-induced oxidative damage in HPF-1 cell by oxidized phenolic compounds present in black tea. Food Chem. 2007;105: 1349-56.

31. Turkmen N, Velioglu YS, Sari F, Polat G. Effect of extraction conditions on measured total polyphenol contents and antioxidant and antibacteria activities of black tea. Molecules. 2007:12:484-96.

32. Shalini D, Sudha G. Antioxidative activity of various tea extracts (Camellia sinensis). J Biosci Res. 2010;1(4):271-8.

33. Erol NT, Sarı F, Velioglu YS. Polyphenols, alkaloids and antioxidant activity of different grades turkish black tea. Gida. 2010;35(3):161-8.

34. Lin JK, Lin-Shiau SY. Mechanisms of hypolipidemic and anti-obesity effects of tea and tea polyphenols. Mol Nutr Food Res. 2006;50:211-7.

35. Imran A, Butt MS, Arshad MS, Arshad MU, Saeed F, Sohaib M, Munir R. Exploring the potential of black tea based flavonoids against hyperlipidemia related disorders. Lipids Health Dis. 2018;17(1):17-57.

36. Chen N, Bezzina R, Hinch E, Lewandowski PA, Cameron-Smith D, Mathai ML, Joise M, Sinclair AJ, Begg DP, Wark JD, Weisinger HS, Weisinger RS. Green tea, black tea, and epigallocatechin modify body composition, improve glucose tolerance, and differentially alter metabolic gene expression in rats fed a high-fat diet. Nutr Res. 2009;29:784-93.

37. Shimada K, Kawarabayashi T, Tanaka A, Fukuda D, Nakamura Y, Yoshiyama M, Takeuchi K, Sawaki T, Hosoda K, Yoshikawa J. Oolong tea increases plasma adiponectin levels and low-density lipoprotein particle size in patients with coronary artery disease. Diabetes Res Clin Pract. 2004;65:227-34.

38. van Tits $L H$, Stienstra $R$, van Lent $P L$, Netea MG, Joosten LAB, Stalenhoe AFH. Oxidized LDL enhances pro-inflammatory responses of alternatively activated M2 macrophages: a crucial role for Krüppel-like factor 2. Atherosclerosis. 2011;214:345-9.
39. Huang HC, Lin JK. Pu-erh tea, green tea, and black tea suppresses hyperlipidemia, hyperleptinemia and fatty acid synthase through activating AMPK in rats fed a high-fructose diet. Food Func. 2012;3:170.

40. Imada S, Tanaka A, Nishiumi S, Ashida H. Concentration of catechins and caffeine in black tea affects suppression of fat accumulation and hyperglycemia in high-fat diet-fed mice. Food Sci Technol Res. 2011; 17(4):353-9.

41. Qin B, Polansky MM, Harry D, Anderson RA. Green tea polyphenols improve cardiac muscle mRNA and protein levels of signal pathways related to insulin and lipid metabolism and inflammation in insulin resistant rats. Mol Nutr Food Res. 2010:54:14-23.

42. Elshater AA, Salman MMA, Moussa MMA. Effect of green tea consumption on level of glucose, lipid profile and kidney functions in alloxan induceddiabetic rats. Egypt Acad J Biol Sci. 2008;1(2):125-34.

43. Adhikary B, Yadav SK, Roy K, Bandyopadhyay SK, Chattopadhyay S. Black tea and theaflavins assist healing of indomethacin-induced gastric ulceration in mice by antioxidative action. Evid Based Complement Alternat Med. 2011;2011:546-60.

44. Gosslau A, Li en Jao D, Huang MT, Ho CT, Evans D, Rawson NE, Chen KY. Effects of the black tea polyphenol theaflavin-2 on apoptotic and inflammatory pathways in vitro and in vivo. Mol Nutr Food Res. 2011;55(2): 198-208.

45. Bahorun T, Luximon-Ramma A, Gunness TK, Sookar D, Bhoyroo S, Jugessur R, Reebye D, Googoolye K, Crozier A, Aruoma OI. Black tea reduces uric acid and $\mathrm{C}$-reactive protein levels in humans susceptible to cardiovascular diseases. Toxicol. 2009;278(1):68-74

46. Bahorun T, Luximon-Ramma A, Neergheen-Bhujun VS, Gunness TK, Googoolye K, Auger C, Crozier A, Aruoma OI. The effect of black tea on risk factors of cardiovascular disease in a normal population. Prev Med. 2012;54:98-102

Ready to submit your research? Choose BMC and benefit from

- fast, convenient online submission

- thorough peer review by experienced researchers in your field

- rapid publication on acceptance

- support for research data, including large and complex data types

- gold Open Access which fosters wider collaboration and increased citations

- maximum visibility for your research: over $100 \mathrm{M}$ website views per year

At BMC, research is always in progress.

Learn more biomedcentral.com/submissions 